\title{
Well-being and associated factors among elementary school teachers in southern Brazil
}

\author{
Mariane Lopez Molina ${ }^{(1)}$ \\ Amanda Rodrigues Fialho(1) \\ Paulinia Leal do Amaral(1) \\ Suelen de Lima Bach ${ }^{(1)}$ \\ Luise Marques da Rocha ${ }^{(1)}$ \\ Luciano Dias de Mattos Souza ${ }^{(1)}$
}

(1) Universidade Católica de Pelotas, Pelotas, Rio Grande do Sul, Brazil.

Conflict of interest: Nonexistent

Received on: February 10, 2017 Accepted on: September 13, 2017

Mailing address:

Mariane Lopez Molina

Rua Gonçalves Chaves, 373 Prédio C, sala $411 \mathrm{C}$ - Centro

CEP: 96015-560 - Pelotas, RS, Brasil

E-mail: mariane_lop@hotmail.com

\section{ABSTRACT}

Purpose: to verify the prevalence of well-being and its association with sociodemographic features, health and work-related conditions, and vocal behavior in elementary school teachers in the city of Pelotas, RS.

Methods: a cross-sectional observational study with 575 teachers from urban and rural areas. The participants answered a structured questionnaire that included items on sociodemographic, health and work-related conditions. The Faces Scale (Andrews) was used to evaluate their psychological well-being. The Vocal Behavior Profile verified occurrences of abuse and vocal misuse. Poisson regression was used for the multivariate analysis.

Results: of the total sample, $79.5 \%$ of teachers experienced well-being. It was observed that vocal behavior profile was significantly associated with well-being, and the number of students in the classroom showed a trend towards significance.

Conclusion: most teachers had a satisfactory well-being perception. Moreover, a lower well-being perception in the teaching population was mainly related to abusive vocal behavior and, less clearly, to the high number of students per classroom.

Keywords: Teachers; Personal Satisfaction; Voice 


\section{INTRODUCTION}

Well-being can be understood as the degree to which individuals judge the overall quality of their lives as a whole favorably. It also consists in a positive evaluation of somebody's experiences in terms of affection and cognition ${ }^{1,2}$. Most of the health studies have the disease as the main outcome at different dimensions ${ }^{3}$. Despite positive health outcomes, such as the wellbeing construct that has been investigated in different populations ${ }^{4-6}$, there is still significant lack of theoretical consensus and measurement methods.

In this sense, the subjective evaluation of well-being can be influenced by several individual and social features. Among these, the physical and psychosocial work-related conditions have been highly associated with physical and mental health indicators in previous studies 7,8

Regarding the teacher population, the literature shows that adverse teaching conditions, such as high workload, double working hours, high number of students per classroom and noise, can significantly affect well-being rates and even the quality of life of these educators ${ }^{9,10}$. Another aspect that seems to be associated with a worse work ability in teachers is the presence of voice disorders, since voice is the teacher's work tool ${ }^{11,12}$.

However, it should be pointed out that the way in which the work-related conditions affect professionals varies from context to context, from person to person 13. Thus, specific conditions of work organization and physical characteristics of the school setting may not be the most important predictors when evaluating subjective health problems in teachers, such as mental health disorders ${ }^{14}$.

While investigations on mental disorders in teachers have been presented in a clear and consistent way ${ }^{15}$, studies focusing on the positive aspects of health in this population are still scarce ${ }^{10,16}$. It is believed that addressing such aspects is relevant to recognize subjective measures as markers of health self-perception, and to provide data that subsidize preventive and protective actions of these professionals.

Therefore, it was hypothesized that greater wellbeing perceptions would be related to better physical health, including the use of the voice in teaching. In addition, more favorable organizational and demand conditions would also be associated with higher wellbeing rates. Therefore, the purpose of the present study was to verify the well-being prevalence and its association with sociodemographic features, health and work-related conditions, and vocal behavior in elementary school teachers in the city of Pelotas, RS-Brazil.

\section{METHODS}

This research was approved by the Research Ethics Committee of the Universidade Católica de Pelotas, under protocol number 2011/29. All teachers signed a written informed consent before answering the questionnaires. Those with signs of vocal impairment were referred to specialized care at the Centro de Referência em Saúde do Trabalhador.

A cross-sectional observational study was carried out at municipal schools in the urban and rural areas of the city of Pelotas. Considering the total population of 2,194 teachers from 103 municipal elementary schools and the objectives of the major research from which this study derived, the required sample number was 662 , including $20 \%$ for control of confounding factors, losses and refusals. Thus, a stratified random sample selection was carried out and 556 teachers from 18 urban schools and 106 teachers from 13 rural schools were selected to participate in this study.

Sample capitation was performed in the selected schools. The inclusion criteria was accepting to participate in the study, and the exclusion criteria was to be physical education (PE) teachers, as their educational characteristics differ considerably from the classroom teachers. However, due the lack of information regarding the number of PE teachers and/or two different registrations in the municipal service registry, a total of 633 teachers were invited to participate; 58 were considered as refusals or losses or did not answer the evaluation tools, resulting in a final sample of 575 teachers.

Teachers answered a self-applied structured questionnaire, which contained questions on the following items: socio-demographic data (gender, age, socioeconomic status and education), health conditions (self-reported disease, tobacco use, and vocal rest) and work (sick leave due to voice, teaching time, workload, overtime, number of students per classroom and the school grades).

Well-being assessment was performed using the Andrews Faces Scale ${ }^{17}$. It is a visual scale composed of seven schematic faces whose expressions vary from extreme happiness to extreme sadness. Respondents pointed to the face that best represented the way they felt, most of the time, in the last month. Responses were then scored from 1 ("very happy") to 7 ("very 
unhappy"). Therefore, the lower the score, the greater the degree of well-being perceived by the interviewee. As an outcome of this work, responses 1,2 and 3 were considered as well-being ${ }^{3}$.

Socioeconomic status was measured using the classification proposed by the Brazilian Economic Indicator (Indicador Econômico Nacional - IEN) based on the 2000 Demographic Census ${ }^{18}$. The sample was divided into tertiles and placed into lower, middle or upper economic classes.

Teachers vocal behavior was verified by the Vocal Behavior Profile ${ }^{19}$, composed of 28 questions was developed to identify situations of abuse and vocal misuse as well as adverse conditions for vocal health. The score was determined as follows: 0 point indicates never, 1 point rare occurrence, 2 points low frequency, 3 points high occurrence and 4 points constant occurrence. Through the sum of the total score, the vocal profile was classified as "behaved/candidate for vocal problems" ( $\geq 30$ points), "serious risk" (from 31 to 50 points), and "champion of abuses" ( $\geq 51$ points).

The data were typed twice, with subsequent review to verify possible failures in filling, including automatic checks for consistency and amplitude by the Epi-Info ${ }^{\mathrm{TM}}$ 6.04. Data analysis was performed in the SPSS 22.0 software. Relative and absolute frequencies of the variables were described in the univariate analysis. Chi-square test was used in the bivariate analysis, aiming to describe associations between well-being and the independent variables. Finally, multivariate analysis was performed by Poisson regression ${ }^{20}$.

The study variables that obtained $p \leq 0.20$ in the bivariate analysis were divided into two hierarchical models: the first level composed of demographic variables (socioeconomic status) and working conditions (school location, the school grades), number of students per classroom); in the second level, the variables of health conditions (self-reported disease and tobacco use) and vocal behavior (voice behavior profile and sick leave due to voice). ${ }^{21}$ Significance levels were set at $p<0.05$.

\section{RESULTS}

In the present study, females were more prevalent $(91.3 \%)$, with up to 40 years of age $(50.3 \%)$ and from middle class $(35 \%)$. Concerning education, $51.2 \%$ of the teachers had a postgraduate degree. For healthrelated conditions, $71.6 \%$ of teachers had some selfreported disease and $11.9 \%$ were smokers (Table 1). 
Table 1. Association of well-being with characteristics and health conditions of elementary school teachers in Pelotas, RS, Brazil, 2011 $(\mathrm{n}=575)$

\begin{tabular}{|c|c|c|c|}
\hline Variable & $\begin{array}{l}\text { Total } \\
\text { n (\%) }\end{array}$ & $\begin{array}{c}\text { Well-being } \\
\text { n (\%) }\end{array}$ & p-value* \\
\hline Gender & & & 0.930 \\
\hline Female & $525(91.3)$ & $418(79.6)$ & \\
\hline Male & $50(8.7)$ & $39(78.0)$ & \\
\hline Age (years)** & & & 0.315 \\
\hline Up to 40 & $279(50.3)$ & $226(81.0)$ & \\
\hline 41 or more & $276(49.7)$ & $213(77.2)$ & \\
\hline Economic status $^{\star \star}$ & & & 0.129 \\
\hline Lower & 173 (33.3) & $132(76.3)$ & \\
\hline Middle & $182(35.0)$ & $143(78.6)$ & \\
\hline Upper & $165(31.7)$ & $137(83.0)$ & \\
\hline Education** & & & 0.670 \\
\hline High school & $43(7.5)$ & $34(79.1)$ & \\
\hline Graduate & 237 (41.3) & $186(78.5)$ & \\
\hline Post-graduate & $294(51.2)$ & $236(80.3)$ & \\
\hline Self-reported disease ${ }^{\star *}$ & & & 0.009 \\
\hline No & $155(28.4)$ & $135(87.1)$ & \\
\hline Yes & $391(71.6)$ & $300(76.7)$ & \\
\hline Tobacco use ${ }^{\star \star}$ & & & 0.020 \\
\hline Never & $413(73.5)$ & $333(80.6)$ & \\
\hline Past & $82(14.6)$ & $70(85.4)$ & \\
\hline Current & $67(11.9)$ & $43(64.2)$ & \\
\hline
\end{tabular}

* Chi-square test; ${ }^{* *}$ Variable with loss.

Regarding work-related conditions, most of teachers worked in urban schools $(75.8 \%)$, had up to 10 years of teaching $(47.2 \%)$, had a weekly workload of between 21 and 40 hours $(62.7 \%)$ and did not work overtime (78.3\%). The majority taught between $1^{\text {st }}$ and $4^{\text {th }}$ grades $(66.7 \%)$ and had up to 25 students per classroom (75.9\%). Concerning the vocal behavior profile, $49.2 \%$ of the sample was considered champion of vocal abuses, $67.6 \%$ reported no vocal rest, and $15 \%$ needed to take sick leave due to voice problems (Table 2).

The prevalence of well-being among teachers was $79.5 \%$. They pointed at one of the three happier faces. In the bivariate analysis, the well-being perception was more prevalent in those who reported not having any disease $(p=0.009)$. In addition, for those who reported a current smoking habit, the well-being prevalence was significantly lower $(p=0.020)$ (Table 1$)$.
For the association of well-being with work-related conditions, a higher prevalence was observed in teachers who had fewer students per classroom $(p=0.012)$. Regarding vocal behavior, those teachers classified as champions of vocal abuses presented worse well-being perception, compared to the other categories $(p=0.005)$. In addition, those who did not take sick leave due to voice problems had a higher prevalence of well-being $(p=0.048)$ (Table 2$)$.

In the multivariate analysis, the only variable that remained significantly associated with well-being was the vocal behavior profile, with a $20 \%$ higher risk of poorer well-being perception compared to those behaved or candidates for vocal problems $(p<0.001)$. In addition, there was a trend towards an association with better well-being perception among teachers with fewer students per classroom $(p=0.076)$ (Table 3$)$. 
Table 2. Association of well-being with work conditions and vocal behavior of elementary school teachers in Pelotas, RS, Brazil, 2011 $(\mathrm{n}=575)$

\begin{tabular}{|c|c|c|c|}
\hline Variable & $\begin{array}{l}\text { Total } \\
\text { n (\%) }\end{array}$ & $\begin{array}{c}\text { Well-being } \\
\text { n (\%) }\end{array}$ & p-value* \\
\hline School location & & & 0.150 \\
\hline Urban & $436(75.8)$ & $353(81.0)$ & \\
\hline Rural & $139(24.2)$ & $104(74.8)$ & \\
\hline Teaching time (years) $^{\star *}$ & & & 0.677 \\
\hline Up to 10 & $269(47.2)$ & $214(79.6)$ & \\
\hline 11 to 20 & $142(24.9)$ & $117(82.4)$ & \\
\hline 21 or more & $159(27.9)$ & $123(77.4)$ & \\
\hline Working hours ** & & & 0.235 \\
\hline Up to 20 & $124(21.6)$ & $101(81.5)$ & \\
\hline 21 to 40 & $359(62.7)$ & 287 (79.9) & \\
\hline 41 or more & $90(15.7)$ & $67(74.4)$ & \\
\hline Overtime** & & & 0.880 \\
\hline No & $445(78.3)$ & $356(80.0)$ & \\
\hline Yes & $123(21.7)$ & $97(78.9)$ & \\
\hline Teaches 1 st to 4 th grades** & & & 0.059 \\
\hline No & $190(33.3)$ & $142(74.7)$ & \\
\hline Yes & $381(66.7)$ & $312(81.9)$ & \\
\hline Students per classroom ${ }^{\star *}$ & & & 0.012 \\
\hline Up to 25 & $422(75.9)$ & $344(81.5)$ & \\
\hline 26 or more & $134(24.1)$ & $95(70.9)$ & \\
\hline Vocal behavior profile** & & & 0.005 \\
\hline Behaved or candidate for vocal problems & $52(10.4)$ & $44(84.6)$ & \\
\hline Serious risk for vocal problems & $203(40.4)$ & $172(84.7)$ & \\
\hline Champion of vocal abuses & $247(49.2)$ & $181(73.3)$ & \\
\hline Does vocal rest ${ }^{* *}$ & & & 0.546 \\
\hline No & $388(67.6)$ & $305(78.6)$ & \\
\hline Yes & $186(32.4)$ & $151(81.2)$ & \\
\hline Sick leave due to voice problems ${ }^{\star *}$ & & & 0.048 \\
\hline No & $488(85.0)$ & $395(80.9)$ & \\
\hline Yes & $86(15.0)$ & $61(70.9)$ & \\
\hline
\end{tabular}

${ }^{*}$ Chi-square test; ${ }^{*}$ Variable with loss. 
Table 3. Poisson regression indicating associated factors with well-being in elementary school teachers in Pelotas, $2011(\mathrm{n}=575)$

\begin{tabular}{|c|c|c|}
\hline Variable & RR (CI95\%) & p-value \\
\hline \multicolumn{3}{|c|}{$1^{\text {st }}$ Level } \\
\hline Economic status & & 0.141 \\
\hline Lower & Reference & \\
\hline Middle & $1.03(0.92-1.15)$ & \\
\hline Upper & $1.09(0.98-1.23)$ & \\
\hline School location & & 0.111 \\
\hline Urban & Reference & \\
\hline Rural & $0.90(0.80-1.02)$ & \\
\hline Teaches 1st to 4th grades & & 0.173 \\
\hline No & Reference & \\
\hline Yes & $1.07(0.97-1.19)$ & \\
\hline Students per classroom & & 0.076 \\
\hline Up to 25 & Reference & \\
\hline 26 or more & $0.90(0.80-1.01)$ & \\
\hline \multicolumn{3}{|c|}{$2^{\text {nd }}$ Level } \\
\hline Self-reported disease & & 0.127 \\
\hline No & Reference & \\
\hline Yes & $0.93(0.84-1.02)$ & \\
\hline Tobacco use & & 0.146 \\
\hline Never & Reference & \\
\hline Past & $1.05(0.94-119)$ & \\
\hline Current & $0.84(0.69-1.01)$ & \\
\hline Vocal behavior profile & & $<0.001$ \\
\hline Behaved or candidate for vocal problems & Reference & \\
\hline Serious risk for vocal problems & $0.95(0.82-1.08)$ & \\
\hline Champion of vocal abuses & $0.80(0.69-0.93)$ & \\
\hline Sick leave due to voice problems & & 0.227 \\
\hline No & Reference & \\
\hline Yes & $0.90(0.76-1.06)$ & \\
\hline
\end{tabular}

$\mathrm{RR}=$ relative risk $\mathrm{Cl} 195 \%=$ confidence interval of $95 \%$

\section{DISCUSSION}

The present research found a high prevalence of well-being among elementary school teachers. It was also possible to verify that greater well-being perception was present among the teachers who presented a profile of vocal behavior characterized by better use of voice. In addition, a trend towards greater well-being was observed among teachers who taught in classes with fewer students.

The present cross-sectional study contains an important limitation that includes the impossibility of establishing a causal association between the exposures and the outcome, as well as indicating the direction of the observed association and the temporal sequence of events. The main strengths are the use of analogical-visual scales such as faces, that have provided a more direct representation of feelings, when compared to the verbal translation necessary to answer a question on this subject ${ }^{17}$, and the large sample of elementary public school teachers who participated in this research.

The prevalence of well-being among elementary school teachers was $79.5 \%$, indicating that they evaluated their own lives in a positive way. Investigations on the levels of well-being and possible associated factors in different populations are scarce in the international literature and almost nonexistent in Brazil ${ }^{4}$. Comparing the well-being prevalence of teachers interviewed $(79.5 \%)$ to the adolescent population, using the same method of measurement, the proportion of well-being observed was higher in the group of youngsters (85.3 and $89.6 \%)^{5,22}$. Sociocultural characteristics related to the different age groups investigated may 
explain the small difference, since a lower well-being perception was related to perceived age-related loss of the human development cycle ${ }^{23}$. In adolescence, performance scores related to quality of life are higher than in adult life ${ }^{24}$.

Conversely, Kidger et al. ${ }^{16}$ found in their research in the United Kingdom low scores of well-being perception specifically among teachers. It is possible that such a difference, of higher well-being scores among the Brazilian population, is influenced by specific sociocultural characteristics of the country, since the wellbeing perception varies according to regional and socioeconomic characteristics ${ }^{25}$. Although the Brazilian sample was exposed to unfavorable working-related conditions ${ }^{26}$, most teachers had a favorable perception, which can be explained by factors, such as being satisfied with their work, social support and good coping strategies, important aspects that guarantee the general well-being of people ${ }^{27}$.

Regarding the work-related conditions, the teachers with more than 25 students in the classroom had a lower proportion of well-being. Other studies have shown a similar association between well-being and the characteristics of the teaching work. The number of students per classroom was correlated to the burnout scores in the study of Carlotto and Palazzo (2006) ${ }^{28}$. In turn, Kidger et al. ${ }^{16}$ observed that lower well-being was associated with working in schools with higher requirement for tasks and performance.

In a qualitative study conducted with university professors from Iraq, more interactive educational practices were implemented and the number of students per classroom was reduced ${ }^{29}$. This has resulted in positive reports of experience and performance by teachers, despite challenges related to poor infrastructure and lack of resources. These findings may justify the tendency toward the association between well-being with lower number of students per classroom. Also, it may be inferred that task overload and the lack of adequate teaching methodologies can impair the sense of self-efficacy and result in worse subjective assessments of well-being among teachers. In addition, although the p-value found is higher than 0.05 , the interpretation of the result indicates that the difference in well-being prevalence observed is less than $8 \%$ more likely to be explained by chance.

Although other studies contemplate the relationship of vocal symptoms with the emotional scope of teachers
${ }^{30}$, with the capacity to perform activities at work ${ }^{11,12}$, and with psychosocial and work organizational characteristics ${ }^{31}$, the present study is a pioneer in the field by presenting the association between vocal behavior profile and well-being in teachers. A higher proportion of well-being perception was observed among teachers who reported good vocal behaviors or presented lower risk of vocal problems. Usually, literature presents an association between emotional and vocal problems ${ }^{32,33}$, however, this new finding suggests that well-being may contribute to the use of more assertive coping strategies focused on occupational problems, such as better use of voice in the classroom ${ }^{34}$.

This suggestion should be interpreted with caution due the research design. However, in a longitudinal study, it was observed that the presence of mental disorders is a risk factor for incidence of vocal problems 35. The presence of mental disorders is commonly associated with a lower proportion of wellbeing ${ }^{36}$ and dysfunctional coping strategies ${ }^{37}$, and may contribute to poor voice use ${ }^{34}$. Emphasis is placed on the need to understand the factors that protect workers' health, so that preventive and protective strategies can be considered based on the individual abilities. We also emphasize the paucity of specific research on positive aspects of health, considering that this gap in the scientific literature lacks consensus and discussion.

\section{CONCLUSION}

Based on the results obtained, we conclude that most elementary school teachers have a satisfactory sense of well-being. Moreover, the lower well-being perception in the teaching population is mainly related to abusive vocal behavior and, less clearly, to the high number of students per classroom.

\section{REFERENCES}

1. Veenhoven R. Questions on happiness: Classical topics, modern answers, blind spots. In: Strack $F$, Argyle $M$ (Eds.). Subjective Wellbeing an Interdisciplinary Perspective. London: Pergamon Press; 1991. p.7-26.

2. Giacomoni $\mathrm{CH}$. Bem-estar subjetivo: em busca da qualidade de vida. Temas em Psicol da SBP. 2004;12(1):43-50.

3. Sparrenberger F, Santos I dos, Lima R da C. Associação de eventos de vida produtores 
de estresse e mal-estar psicológico: um estudo de base populacional. Cad Saúde Pública. 2004;20(1):249-58. doi: 10.1590/ S0102-311X2004000100042.

4. Hallal PC, Dumith SC, Scalco DL, Menezes AMB, Araújo CL. Well-being in adolescents: the 11-year follow-up of the 1993 Pelotas (Brazil) birth cohort study. Cad Saude Publica. 2010;26(10):1887-94. doi:http://dx.doi.org/10.1590/ S0102-311X2010001000004.

5. Silva RA da, Horta BL, Pontes LM, Faria AD, Souza LDM, Cruzeiro ALS et al. Bem-estar psicológico e adolescência: fatores associados. Cad Saude Publica 2007;23(5):1113-1118. doi:10.1590/ S0102-311X2007000500013.

6. Dear $\mathrm{K}$, Henderson S, Korten A. Well-being in Australia: Findings from the National Survey of Mental Health and Well-being. Soc Psychiatry Psychiatr Epidemiol. 2002;37(11):503-9. doi:10.1007/s00127-002-0590-3.

7. Gomes AR, Silva MJ, Mourisco S, Silva S, Mota A, Montenegro N. Problemas e desafios no exercício da actividade docente : Um estudo sobre o stresse, "burnout", saúde física e satisfação profissional em professores do $3^{\circ}$ ciclo e ensino secundário. Rev Port Educ. 2006;19(1):67-93.

8. Thomas G, Kooijman PGC, Cremers CWRJ, Jong FICRS. A comparative study of voice complaints and risk factors for voice complaints in female student teachers and practicing teachers early in their career. Eur Arch Otorhinolaryngol. 2006;263(4):370-80. doi:10.1007/s00405-0051010-6.

9. Xavier CES, Morais AS de. Qualidade de vida em professores da rede pública estadual de ensino da cidade de Aracaju-SE. Rev Bras Prescrição e Fisiol do Exerc. 2007;1(5):85-94. ISSN 1981-9900.

10. Damásio BF, Melo RLP de, Silva JP. Meaning in life, psychological well-being and quality of life in teachers sentido de vida. Paidéia. 2013;23(54):73-82.

11. Ferreira LP, Giannini SPP, Alves NLL, Brito AF, Andrade BMR, Latorre MRDO. Voice disorder and teaching work ability. Rev. CEFAC. 2016;18(4):932-40. doi: 10.1590/1982-0216201618421615.

12. Giannini SPP, Latorre MRDO, Fischer FM, Ghirardi ACAM, Ferreira LP. Teachers' voice disorders and loss of work ability: a case-control study.
Journal of Voice. 2014;29(2):1-9. doi:10.1016/j. jvoice.2014.06.004. [in press]

13. Sadir MA, Bignotto MM, Lipp MEN. Stress e qualidade de vida: influência de algumas variáveis pessoais. Paideia. 2010;20(45):73-81. doi:10.1590/ S0103-863X2010000100010.

14. Seibt R, Spitzer S, Druschke D, Scheuch K, Hinz A. Predictors of mental health in female teachers. Int J Occup Med Environ Health. 2013;26(6):856-69. doi:10.2478/s13382-013-0161-8.

15. Stansfeld SA, Rasul FR, Head J, Singleton $N$. Occupation and mental health in a national UK survey. Soc Psychiatry Psychiatr Epidemiol. 2011;46(2):101-10. doi:10.1007/ s00127-009-0173-7.

16. Kidger J, Brockman R, Tilling K, Campbell R, Ford $T$, Araya $R$ et al. Teachers' wellbeing and depressive symptoms, and associated risk factors: A large cross sectional study in English secondary schools. J Affect Disord. 2016;192:76-82. doi:10.1016/j. jad.2015.11.054.

17. Mcdowell I. Measuring health: a guide to rating scales and questionnaires. New York: Oxford University Press; 2006Third Edition. Vol $8 .$. doi:10.1093/aje/155.10.899.

18. Barros AJD, Victoria CG. A nationwide wealth score based on the 2000 Brazilian demographic census. Rev Saude Publica. 2005;39(4):523-9. doi:10.1590/ S0034-89102005000400002.

19. Behlau M, Pontes P. Perfil de Comportamento Vocal. In: Behlau M, Pontes P (org). Higiene Vocal: Cuidando Da Voz. 4th ed. Rio de Janeiro: Revinter; 2006. p. 79-83.

20. Barros AJD, Hirakata VN. Alternatives for logistic regression in cross-sectional studies: an empirical comparison of models that directly estimate the prevalence ratio. BMC Med Res Methodol. 2003;3:21. doi:10.1186/1471-2288-3-21.

21. Victora CG, Huttly SR, Fuchs SC, Olinto MT. The role of conceptual frameworks in epidemiological analysis: a hierarchical approach. Int $\mathrm{J}$ Epidemiol. 1997;26(1):224-7. doi:10.1093/ije/26.1.224.

22. Souza L, Maragalhoni T, Quincoses M, Jansen K, Cruzeiro AL, Ores $L$ et al. Bem-estar psicológico de jovens de 18 a 24 anos: fatores associados. Cad. Saúde Pública. 2012;28(6):1167-74. doi:10.1590/ S0102-311X2012000600015

23. Brothers A, Gabrian M, Wahl HW, Diehl M. Future time perspective and awareness of age-related change: examining their role in predicting 
psychological well-being. Psychol Aging. 2016;31(6):605-17. doi: 10.1037/pag0000101

24. Jörngården $A$, Wettergen $L$, von Essen $L$. Measuring health-related quality of life in adolescents and young adults: Swedish normative data for the SF-36 and the HADS, and the influence of age, gender, and method of administration. Health Qual Life Outcomes. 2006;4:91. doi: 10.1186/1477-7525-4-91

25. Ngamaba KH. Determinants of subjective well-being in representative samples of nations. Eur J Public Health. 2017:27(2):377-382. doi: 10.1093/ eurpub/ckw103.

26. Andrade PP, Veiga HMS. Avaliação dos Trabalhadores acerca de um programa de qualidade de vida no trabalho: validação de escala e análise qualitativa. Psicologia: Ciência \& Profissão. 2012;32(2):304-19.

27. OMS: Organização Mundial da Saúde. Relatório Mundial da Saúde. Saúde Mental: Nova concepção, nova esperança. [cited 2002 Abr 15] Disponível em: [http://www.who.int/whr/2001/en/ whr01_djmessage_po.pdf]

28. Carlotto MS, Palazzo LS. Síndrome de burnout e fatores associados: um estudo epidemiológico com professores. Cad Saúde Pública. 2006;22(5):1017-26. doi: 10.1590/ S0102-311X2006000500014

29. Saleh AM, Shabila NP, Dabbagh AA, Al-Tawil NG, Al-Hadithi TS. A qualitative assessment of faculty perspectives of small group teaching experience in Iraq. BMC Med Educ. 2015;15 L.S.:19. doi: 10.1186/s12909-015-0304-7

30. Santos SMM, Medeiros JSA, Gama ACC, Teixeira LC, Medeiros AM. Voice impact in the social communication and emotion of teachers before and after speech therapy. Rev. CEFAC. 2016;18(2):470-80. doi: 10.1590/1982-0216201618211015

31. Gomes NR, Medeiros, AM, Teixeira, LC. Self-perception of working conditions by primary school teachers. Rev. CEFAC. 2016;18(1):167-73. doi: 10.1590/1982-021620161819515

32. Roy N, Merrill RM, Thibeaults S, Gray SD, Smith EM. Voice disorders in teachers and the general population: effects on work performance, attendance, and future carrer choices. J Speech Lang Hear Res. 2004;47(3):542-51. doi: 10.1044/1092-4388(2004/042)

33. Nerriére E, Vercambre MN, Kovess-Masféty FG, Kovess-Masféty $\mathrm{V}$. Voice disorders and mental health in teachers: a cross-sectional nationwide study. J. BMC Public Health. 2009;9 L.S.:1-8. doi: 10.1186/1471-2458-9-370

34. Oliveira G, Hirani SP, Epstein R, Behlau M. Coping strategies in voice disorders of a Brazilian population. J Voice. 2012;26(2):205-13. doi: 10.1016/j.jvoice.2010.10.023

35. Rocha LM, Bach SL, Amaral PL, Behlau M, Souza LDM. Risk factors for the incidence of perceived voice disorders in elementary and middle school teachers. J Voice. 2016;31(2):258.e7-258.e12. doi: 10.1016/j.jvoice.2016.05.018

36. Nepomuceno BB, Cardoso AA, Ximenes VM, Barros JP, Leite JF. Mental health, well-being, and poverty: A study in urban and rural communities in Northeastern Brazil. J Prev Interv Community. 2016;44(1):63-75. doi: 10.1080/10852352.2016.1102590

37. Mayordomo T, Viguer P, Sales A, Satorres E, Meléndez JC. Resilience and Coping as Predictors of Well-Being in Adults. J Psychol. 2016;150(7):1-13. doi: 10.1080/00223980.2016.1203276. 